\title{
WSPOMNIENIE
}

\section{Profesor Józef Darski, Przewodniczący PTN w latach 1989-1992}

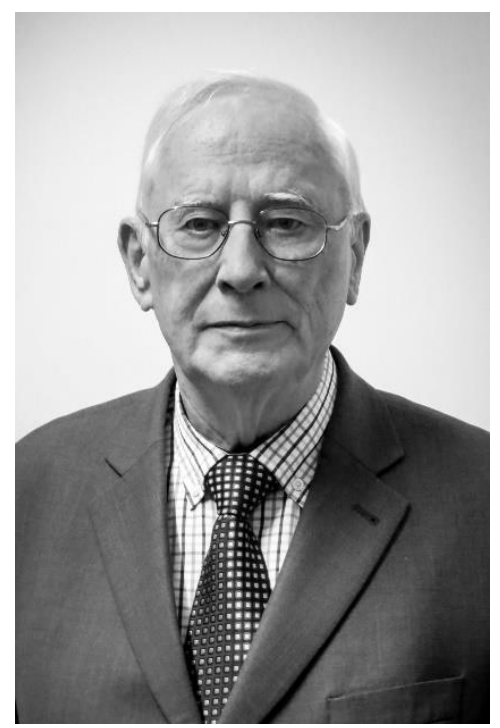

18 marca 2016 roku zmarł prof. dr hab. Józef Darski, emerytowany profesor Uniwersytetu im. Adama Mickiewicza w Poznaniu. Był wybitnym językoznawcą, twórcą lingwistycznego modelu analizy języka naturalnego, autorem wielu cenionych publikacji, uczonym, zawsze życzliwym studentom i adeptom nauki.

Po ukończeniu filologii germańskiej na Uniwersytecie im. Adama Mickiewicza w Poznaniu w 1965 roku podjął pracę jako stażysta w Katedrze Języków Germańskich. W 1974 roku obronił pracę doktorską, a w 1987 uzyskał tytuł doktora habilitowanego. Tytuł naukowy profesora otrzymał w roku 1999. Jego dokonania badawcze, publikowane w prestiżowych czasopismach krajowych i zagranicznych, obejmowały cztery obszary badawcze. Początkowo zajmował się dialektologią, której poświęcił swą dysertację doktorską. W następnych latach 
głównym przedmiotem jego badań był system współczesnego języka niemieckiego. Opracowany w wyniku tych badań analityczny model lingwistyczny od wielu lat stanowi inspirację dla szeregu badaczy zajmujących się synchronicznym i diachronicznym opisem języka. Kolejnym obszarem badawczym były studia konfrontatywne w zakresie języka polskiego i niemieckiego. W swych badaniach podjął także zagadnienia dydaktyki dotyczące podsystemów językowych, formułując inspirujące przemyślenia w zakresie prezentacji materiału, aspektów uczenia się i przyswajania języka obcego.

Należał do grona cenionych promotorów licznych prac doktorskich, magisterskich, licencjackich - zawsze gotowym do poświęcenia dodatkowego czasu seminarzystom. Był recenzentem w wielu przewodach doktorskich, habilitacyjnych oraz postępowaniach profesorskich. Przez wiele lat pracował również w Państwowej Wyższej Szkole Zawodowej w Koninie.

Na wielki szacunek zasługuje jego działalność organizacyjna. Przez szereg lat pełnił funkcję prodziekana ds. nauki na Wydziale Neofilologii UAM oraz dziekana tego wydziału. Był założycielem i długoletnim kierownikiem Zakładu Gramatyki Opisowej Języka Niemieckiego. Organizował konferencje naukowe i pracował w komitetach redakcyjnych czasopism. Wśród licznych wystąpień konferencyjnych w kraju i za granicą wspomnieć należy referaty, które wygłosił na konferencjach naukowych Polskiego Towarzystwa Neofilologicznego w Zielonej Górze oraz w Lublinie.

We wrześniu 1988 r. prof. Józef Darski został wybrany przez Walny Zjazd PTN na przewodniczącego Zarządu Głównego. Z jego inicjatywy powstała szkoła języków obcych Neofilolog, działająca w Poznaniu pod patronatem PTN. Pozyskane w ten sposób fundusze pomogły zapewnić działalność statutową Towarzystwa w tych trudnych czasach. Profesor pełnił także funkcję wiceprzewodniczącego Stowarzyszenia Germanistów Polskich oraz przewodniczącego sekcji niemieckiej Państwowej Komisji Egzaminacyjnej.

Był dwukrotnym stypendystą fundacji im. Aleksandra Humboldta. Za swą działalność otrzymał wiele odznaczeń i wyróżnień, m.in. Złoty Krzyż Zasługi, Medal Komisji Edukacji Narodowej, Nagrodę Ministra Nauki i Szkolnictwa Wyższego oraz Krzyż Kawalerski Odrodzenia Polski.

Wraz z odejściem profesora Józefa Darskiego nauka polska straciła wybitnego uczonego, a także nauczyciela akademickiego, który cieszył się szacunkiem współpracowników, młodej kadry naukowej i studentów.

Profesor Józef Darski był wrażliwym, skromnym i na wskroś uczciwym człowiekiem o ogromnym dorobku naukowym. Pozostanie dla nas, Jego uczniów i przyjaciół, wzorem uczonego oraz nauczyciela akademickiego. 